\title{
PENGARUH PIJAT KAKI TERHADAP PENURUNAN TEKANAN DARAH PADA IBU HAMIL DENGAN HIPERTENSI DI RS YOGYAKARTA
}

\section{EFFECT OF FOOT MASSAGE ON DECREASING BLOOD PRESSURE IN PREGNANT WOMEN WITH HYPERTENSION IN YOGYAKARTA}

\author{
Retno Mawarti ${ }^{1 *}$, Lailatuz Zaidah $^{2}$ \\ ${ }^{* 1}$ Universitas 'Aisyiyah Yogyakarta, Jalan Ringroad Barat No.63, Gamping, Sleman, Daerah Istimewa \\ Yogyakarta, rossa_mate@yahoo.com, Indonesia \\ ${ }^{2}$ Universitas 'Aisyiyah Yogyakarta, Jalan Ringroad Barat No.63, Gamping, Sleman, Daerah Istimewa \\ Yogyakarta Institusi, lailafisioterapis@yahoo.com, Indonesia
}

\begin{abstract}
Background: Hypertension in pregnancy is a disease that gets attention given the negative effects it has on both the mother and the fetus. Hypertension in pregnancy if not treated properly will develop into superimposed Preeclampsia along with the increase in gestational age. Massage with aromatherapy oil is a non-pharmacological therapy to reduce and maintain blood pressure in a range that can be tolerated by the body.

Objective: This study aims to determine the effect of a foot massage with lavender essential oil on reducing blood pressure in pregnant women with hypertension.

Methods: The methodology used in this study was pre-experimental with the control group. Respondents consist of 15 pregnant women with hypertension who had been given blood pressure-lowering therapy, 8 people performed foot massage and 7 people made the control with accidental sampling technique. Massage with lavender essential oil conducted for 15-20 minutes every day for 7 days. Data were obtained by measuring blood pressure before and after the intervention, and then recorded into the observation sheet. The control group performed pressure measurements before and after given by blood pressure-lowering drugs, then analyzed by descriptive and bivariate statistical tests.

Results: The results showed that the blood pressure difference before and after systole intervention was 6,52 , diastole 0.82 in the control group of blood pressure difference before and after being given systole drug 7,902 diastole 4,847 Paired t-test results in the systole intervention group 0.340, diastole 0.40 and in the systole control group 0.068 , diastole $0.137(p=0.05)$.

Conclusion: The conclusion is the effect of a foot massage with lavender essential oil in pregnant women with hypertension. Suggestions for pregnant women with primary hypertension should do foot massage to help lower blood pressure.
\end{abstract}

Keywords: Aromatherapy, foot massage, hipertension, lavender, pregnancy.

\section{PENDAHULUAN}

Hipertensi merupakan penyakit yang mendapat perhatian dari seluruh kalangan masyarakat. Dampak yang ditimbulkan baik jangka pendek maupun jangka panjang membutuhkan penanggulangan yang menyeluruh dan terpadu. Hipertensi menimbulkan angka morbiditas (kesakitan) dan mortalitas (kematian) yang tinggi. Penyakit hipertensi menjadi penyebab kematian 7,1 juta orang di seluruh dunia,yaitu sekitar $13 \%$ dari total kematian, prevalensinya hampir sama besar baik di negara berkembang maupun negara maju. ${ }^{1}$ Perkembangan penyakit hipertensi berjalan perlahan tetapi secara potensial sangat berbahaya. Hipertensi merupakan faktor risiko utama dari penyakit jantung dan stroke.

Hipertensi dalam kehamilan merupakan kelainan vaskuler yang terjadi sebelum 
kahamilan atau timbul dalam kehamilan atau pada permulaan nifas. ${ }^{2}$

Dampak hypertensi dalam kehamilan dapat mempengaruhi kerja ginjal berakibat terjadinya protein urine. Apabila seorang ibu hamil mengalami hypertensi dan protein urine diagnesa berubah menjadi Pre Eklamsia, bahkan menjadi Eklampsia. Salah satu penyebab kematian ibu adalah Eklampsia. Dampaknya terhadap ibu dan janin sangat merugikan. Pengendalian hipertensi belum menunjukkan hasil yang memuaskan. Hypertensi pada ibu hamil, dilakukan ANC terpadu, perencanaan persalinan di RS dan pengobatan farmakologi dengan baik. ${ }^{2}$

Teknik pemijatan berdampak terhadap lancarnya sirkulasi aliran darah, menyeimbangkan aliran energi didalam tubuh serta mengendurkan ketegangan otot. Meskipun teknik pemijatan tidak akan berdampak banyak pada penderita hipertensi berat, namun beberapa penelitian telah membuktikan bahwa masase dapat menurunkan tekanan darah pada penderita hipertensi ringan dan sedang. ${ }^{3}$ Vasokonstriksi pada pembuluh darah perifer dapat menghambat sirkulasi darah dan meningkatkan tahanan vaskuler sehingga menyebabkan hipertensi. Salah satu gerakan dalam pemijatan,yaitu effleurage yang dilakukan pada daerah kakidapat menyebabkan vasodilatasi pembuluh darah perifer, dan efeknya memperlancar aliran darah balik dari daerah ekstremitas bawah menuju ke jantung. ${ }^{4}$
Dalam pemilihan aromaterapi yang akan digunakan dalam pemijatan, disesuaikan dengan khasiat dari masingmasing aromatrapi. Minyak esensial lavender paling umum digunakan untuk masase karena kandungan aldehid yang berifat iritatif bagi kulit hanya $2 \%$ serta tidak bersifat toksik. Kandungan ester pada bunga lavender bekerja dengan lembut di kulit dan memberikan efek menenangkan., ${ }^{5,6}$ Masage kaki dengan minyak esensial lavender pada pasien yang mendapat perawatan intensif dapat menurunkan tekanan darah, frekuensi denyut jantung dan pernafasan. ${ }^{7}$

\section{BAHAN DAN CARA PENELITIAN}

Metode penelitian yang dilakukan adalah penelitian eksperimen semu (Quasy Eksperimental), yang merupakan rancangan yang bertujuan untuk mengungkapkan hubungan sebab akibat dengan cara melibatkan kelompok kontrol disamping kelompok eksperimental. Percobaan ini berupa perlakuan atau intervensi terhadap suatu variabel yang diharapkan terjadi perubahan atau pengaruh terhadap variabel yang lain. Desain rancangan adalah Control Group Design, yaitu mengungkapkan hubungan sebab akibat dengan cara melibatkan dua kelompok subjek. Kelompok eksperimental diberikan perlakuan sedangkan kelompok kontrol tidak dilakukan. ${ }^{8}$ Paparan penelitian ini adalah ibu hamil yang mengalami hipertensi di RS Pratama Yogyakarta diberi perlakuan pijat kaki dan di 
RSU Muhamadiyah Yogyakarta sebagai kelompok kontrol tanpa perlakuan (diukur tekanan darah.

\section{HASIL DAN PEMBAHASAN}

Identifikasi karakteristik responden dalam penelitian ini meliputi Pendidikan, Pekerjaan, Umur, Umur Kehamilan, dan Paritas. Karakteristik responden disajikan dalam tabel dibawah ini.

Tabel 1 Distribusi frekuensi Karakteristik

Responden berdasarkan Umur, Pendidikan, Pekerjaan, Umur Kehamilan, Paritas

\begin{tabular}{|c|c|c|c|c|}
\hline \multirow[t]{2}{*}{ Karakteristik } & \multicolumn{2}{|c|}{$\begin{array}{l}\text { Kelompok } \\
\text { Perlakuan }\end{array}$} & \multicolumn{2}{|c|}{$\begin{array}{c}\text { Kelompok } \\
\text { Kontrol }\end{array}$} \\
\hline & $\mathrm{N}$ & $\begin{array}{c}\text { Frekuensi } \\
\%\end{array}$ & $\mathrm{~N}$ & $\begin{array}{c}\text { Frekuensi } \\
\%\end{array}$ \\
\hline \multicolumn{5}{|l|}{ Umur } \\
\hline $\begin{array}{l}<20 \text { tahun } \\
\text { dan }>35\end{array}$ & 3 & 37,5 & 3 & 42.85 \\
\hline 20 th -35 th & 5 & 62,5 & 4 & 57.15 \\
\hline \multicolumn{5}{|l|}{ Pendidikan } \\
\hline $\begin{array}{l}\text { SMA } \\
\text { Akademik }\end{array}$ & $\begin{array}{l}5 \\
3\end{array}$ & $\begin{array}{l}62,5 \\
37,5\end{array}$ & $\begin{array}{l}3 \\
4\end{array}$ & $\begin{array}{l}42,85 \\
57,15\end{array}$ \\
\hline \multicolumn{5}{|l|}{ Pekerjaan } \\
\hline $\begin{array}{l}\text { lbu Rumah } \\
\text { Tangga }\end{array}$ & 6 & 75 & 4 & 57,15 \\
\hline $\begin{array}{l}\text { PNS } \\
\text { Swasta }\end{array}$ & $\overline{2}$ & 25 & $\begin{array}{l}1 \\
2\end{array}$ & $\begin{array}{l}14,28 \\
28,57\end{array}$ \\
\hline
\end{tabular}

\begin{tabular}{lcccc}
\hline $\begin{array}{l}\text { Umur } \\
\text { Kehamilan }\end{array}$ & & & & \\
\hline$\quad$ Trimester I & 4 & 50 & 4 & 57.15 \\
$\quad$ Trimester II & 3 & 37,5 & 2 & 28,57 \\
$\quad$ Trimester III & 1 & 12,5 & 1 & 14,28 \\
\hline Paritas & & & & \\
\hline \multicolumn{1}{c}{ Primigravida } & 1 & 12,5 & 2 & 28,57 \\
$\quad$ Multigavida & 7 & 87,5 & 5 & 71,43 \\
\hline Total & 8 & 100 & 7 & 100 \\
\hline Sumber: Data Primer, & 2018 & &
\end{tabular}

Pada tabel 1, umur responden pada kelompok perlakuan dan kontrol mayorita mempunyai umur produktif 20-35 th pada kelompok perlakuan sebanyak 5 (62,5\%) sedangkan pada kelompok kontrol sebanyak 4 (57,5\%). Pendidikan responden pada kelompok perlakuan mayoritas pendidikan SMA sebanyak 5 (62.5\%),sedangkan pada kelompok kontrol mayoritas pendidikan PT sebanyak 4 $(57,5 \%)$. Pekerjaan responden pada kelompok perlakuan mayoritas sebagai IRT sebanyak 6 (75\%) sedangkan pada pekerjaan pada kelompok kontrol mayoritas sebagai IRT sebanyak 4 (57,15\%).Umur kehamilan responden pada kelompok perlakuan mayoritas hamil TM 1 sebanyak 4 (50\%),sedangkan pada kelompok kontrol Umur kehamilanmayoritas TM1 sebanyak 4 $(57,155 \%)$, . Paritas responden pada kelompok perlakuan mayoritas multigravida sebanyak 7 (87,5\%), sedangkan pada kelompok kontrol mayoritas paritas multigravida sebanyak 5 (71,43\%).

Tabel 2 Distribusi Frekuensi Rata-rata Tekanan Darah Pada Kelompok Perlakuan

\begin{tabular}{lccc}
\hline Uraian & Sebelum & Sesudah & Selisih \\
\hline Systole & 144,140 & 137,638 & 6,502 \\
\hline Diastole & 83,425 & 82,605 & 0,82 \\
\hline Sumber: & Data Primer 2018 &
\end{tabular}

Pada tabel 2, rata-rata sistole sebelum diberi perlakuan 144,140 mmHg, dan setelah diberi perlakuan $137,638 \mathrm{mmHg}$ dengan selisih sebanyak 6,605 $\mathrm{mmHg}$, sedangkan Diastole sebelum diberi perlakuan $83,425 \mathrm{mmHg}$, dan setelah diberi perlakuan $82,605 \mathrm{mmHg}$ dengan selisih $0,82 \mathrm{mmHg}$.

Tabel 3 Distribusi Frekuensi Rata-rata Tekanan Darah Pijat Kaki dengan Minyak Lavender Pada Kelompok Kontrol

\begin{tabular}{cccc}
\hline Uraian & $\begin{array}{c}\text { Sebelum } \\
(\mathbf{m m H g})\end{array}$ & $\begin{array}{c}\text { Sesudah } \\
(\mathbf{m m H g})\end{array}$ & $\begin{array}{c}\text { Selisih } \\
(\mathbf{m m H g})\end{array}$ \\
\hline Systole & 138,237 & 130,335 & 7,902 \\
\hline Diastole & 88,761 & 83,914 & 4,847 \\
\hline
\end{tabular}

Sumber: Data Primer, 2018

Pada tabel 3, rata-rata sistole sebelum diberi diberi obat sebanyak $138,237 \mathrm{mmHg}$, dan setelah diberi obat 
$130,335 \mathrm{mmHg}$ dengan selisih sebanyak $7,902 \mathrm{mmHg}$, sedangkan Diastole sebelum obat $88,761 \mathrm{mmHg}$,dan setelah diberi obat $83,914 \mathrm{mmHg}$ dengan selisih 4,847 $\mathrm{mmHg}$.

Analisa Bivariat menggunakan uji Paired T Test.

Tabel 4 Hubungan Tekanan Darah pada Ibu Hamil dengan Hypertensi Sebelum dilakukan

Pijat Kaki dengan Minyak Lavender Pada Kelompok Perlakuan dan Kontrol Variabel N Correlation Sig.

\begin{tabular}{llll}
$\begin{array}{l}\text { Sistole Pre Perlakuan } \\
\text { \& Sistole Post }\end{array}$ & 8 &, 720 & .044 \\
$\begin{array}{llll}\text { Perlakuan } \\
\text { Diastole Pre }\end{array}$ & & & \\
$\begin{array}{l}\text { Perlakuan \& Diastole } \\
\text { Post Perlakuan }\end{array}$ & 8 &, 958 & .000 \\
\hline
\end{tabular}

Sistole Pre Kontrol \&

$\begin{array}{llll}\text { Sistole Post Kontrol } & 7 & , 618 & .139\end{array}$

Diastole Pre Kontrol \&

Diastole Post Kontrol 150 .748

Sumber: Data Primer, 2018

Pada tabel 4 secara statistik terdapat hubungan sistole dan diastole pada kelompok Perlakuan sebelum dan sesudah perlakuan dengan,.sedangkan pada kelompok Kontrol secara statistik tidak terdapat hubungan sistole dan diastole sebelum dan sesudah perlakuan.

Pada tabel 5, secara statistik tidak terdapat pengaruh sistole pada ibu hamil yang dilakukan pijat kaki (kelompok perlakuan), dan terdapat pengaruh Diastole pada ibu hamil yang dilakukan pijat kaki (kelompok Perlakuan) $\mathrm{p}=0.40$, sedangkan pada kelompok Kontrol secara statistik tidak ada pengaruh pemberian obat farmakologi.
Tabel 5 Pengaruh Pijat Kaki dengan Minyak Lavender pada Ibu Hamil dengan Hypertensi di RS Pratama Kota Yogyakarta tahun 2018

\begin{tabular}{cccc}
\hline Variabel & Mean & $\begin{array}{c}\text { Std. } \\
\text { Deviation }\end{array}$ & $\begin{array}{c}\text { Sig (2- } \\
\text { tailed) }\end{array}$ \\
\hline
\end{tabular}

Sistole Pre

Perlakuan -

Sistole Post $6,50125 \quad 17,95589 \quad 340$

Perlakuan

Diastole Pre

Perlakuan -

Diastole Post $\quad, 82000 \quad, 91855 \quad, 040$

Perlakuan

\begin{tabular}{lrrrr}
\hline Sistole & Pre & & & \\
Kontrol & - & & & \\
Sistole & Post & 7,90143 & 9,41311 &, 068 \\
Kontrol & & & & \\
\hline Diastole Pre & & & \\
Kontrol & - & & & \\
Diastole Post & 4,84714 & 7,47719 &, 137 \\
Kontrol & & & \\
\hline
\end{tabular}
untuk mengetahui pengaruh pijat kaki dalam menurunkan tensi darah pada ibu hamil, penelitian dilakukan di Rumah Sakit Pratama dan RS. PKU Muhammadiyah Yogyakarta, sampel pada penelitian ini berjumlah 8 ibu hamil dengan tensi tinggi dan diberikan perlakuan pijat kaki, serta 7 ibu hamil dengan tensi tinggi yang terkontrol dengan obat. Pada penelitian ini pada masing-masing kelompok dilakukan selama 7 hari berturutturut. Pada penelitian ini karakeristik responden adalah usia, pendidikan, pekerjaan, umur kehamilan dan paritas.

Berdasarkan tabel 1 karakteristik berdasarkan usia, kelompok dengan perlakuan sebanyak 8 responden berusia < 25 tahun, $>35$ tahun sebanyak 3 orang, dan 
yang berusia 25-35 sebanyak 5 responden. Kelompok kontrol sebanyak 7 responden berusia $<25$ tahun, $>35$ tahun sebanyak 3 orang, dan yang berusia 25-35 sebanyak 4 responden. Dari hasil diatas diketahui bahwa ada hubungan antara usia responden dengan kejadian peningkatan tekanan darah pada ibu hamil, hal ini disebabkan karena ibu yang hamil pada usia yang terlalu muda dari segi biologis perkembangan alat-alat reproduksinya belum optimal sedangkan pada usia tua (> 35 tahun) akan menambah terjadinya komplikasi kehamilan,penelitian menunjukkan bahwa dengan bertambahnya umur lbu mengakibatkan absorbsi tubuh cenderung memburuk dan alat reproduksinya sudah mulai degenerasi. ${ }^{2}$

Dengan bertambahnya umur, risiko terkena hipertensi menjadi lebih besar sehingga prevalensi hipertensi dikalangan usia lanjut cukup tinggi. Tingginya hipertensi sejalan dengan bertambahnya umur, hal ini disebabkan oleh perubahan struktur pada pembuluh darah besar,sehingga lumen menjadi lebih sempit dan dinding pembuluh darah menjadi lebih kaku, sebagai akibat adalah meningkatnya tekanan darah sistolik. ${ }^{9}$

Berdasarkan tabel 1 karakteristik berdasarkan Pendidikan, responden yang berpendidikan SMA pada kelompok perlakuan sebanyak 5 responden, sedangkan pada kelompok kontrol sebanyak 3 responden. Sedangkan responden yang bependidikan akademik pada kelompok perlakuan sebanyak 3 responden, sedangkan pada kelompok kontrol sebanyak 4 responden. Dari hasil diatas diketahui bahwa ada hubungan antara pendidikan responden dengan kejadian peningkatan tekanan darah pada ibu hamil. Dengan tingkat Pendidikan yang dimiliki oleh responden maka bisa diketahui tentang pengetahuan dari ibu hamil tentang bahaya terjadinya peningkatan tensi darah pada ibu hamil serta kepatuhan dari ibu hamil dalam pemeriksaan kehamilan ke rumah sakit atau ke bidan terdekat untuk mendeteksi terjadinya hipertensi pada ibu hamil. $^{2,9}$

Berdasarkan tabel 1 karakteristik berdasarkan pekerjaan, pada kelompok responden dengan perlakuan yang bekerja sebagai ibu rumah tangga sebanyak 6 responden, sedangkan pada kelompok responden terkontrol sebanyak 4 responden. Pada responden dengan perlakuan yang bekerja sebagai PNS tidak ada, sedangkan pada kelompok responden terkontrol sebanyak 1 responden. Pada kelompok responden dengan perlakuan yang bekerja swasta sebanyak 2 responden, sedangkan pada kelompok responden terkontrol sebanyak 2 responden. Pekerjaan yang dilakukan oleh ibu hamil haruslah bersifat ringan, tidak melelahkan ibu dan tidak mengganggu kehamilannya.

Pekerjaan dinas misalnya guru dan pegawai kantor, berdagang maupun tenagatenaga perawat boleh meneruskan pekerjaannya sampai waktu cuti hamil asal saja ingat akan pekerjaan yang sifatnya 
memberatkan. Pekerjaan yang sifatnya mengganggu kehamilan dihindarkan misalnya pekerjaan di pabrik rokok, percetakan atau pabrik-pabrik lainnya yang mengeluarkan zat-zat yang dapat menggangu janin dalam kandungannya.

Pekerjaan adalah sesuatu yang dilakukan, diperbuat, dikerjakan untuk mendapatkan nafkah atau menghasilkan uang. Jadi pekerjaan yang dilakukan akan mempengaruhi besar kecilnya pendapatan seseorang, tetap atau tidaknya menerima penghasilan dan waktu menerima gaji atu upah "labour fource concept" yang digolongkan bekerja adalah mereka yang melakukan pekerjaan untuk menghasilkan barang-barang atau jasa-jasa dengan tujuan untuk memperoleh penghasilan atau keuntungan bila mereka bekerja penuh maupun tidak bekerja penuh. Sehubungan antara pekerjaan dan distribusi dan frekuensi masalah kesehatan telah sejak lama diketahui. Pekerjaan lebih banyak dilihat dari kemungkinan keterpaparan. tersebut serta besarnya resiko menurut sifat pekerjaan, juga akan berpengaruh pada lingkungan kerja dan sifat sosial ekonomi karyawan pada pekerjaan tertentu. Interaksi manusia sebagai pekerja dengan pekerjaan dan lingkungan kerja dapat menyebabkan efek positif kepada pekerja, atau efek yang sebaliknya.

Hampir setiap pekerjaan selalu memiliki "agen stress" yang potensial. Pada umumnya, stress pada pekerja terjadi karena interaksi pekerja dengan pekerjaan atau lingkungan kerja,yang ditandai dengan penolakan diri sehingga terjadi penyimpangan secara fungsional.

Hasil penelitian ini sejalan dengan penelitian yang dilakukan oleh di Rumah Bersalin Baji Minahasa menunjukkan bahwa status bekerja ibu merupakan faktor risiko hipertensi. ${ }^{10}$

Berdasarkan tabel 1 karakteristik berdasarkan umur kehamilan, pada kelompok responden dengan perlakuan yang umur kehamilan trimester I sebanyak 4 responden sedangkan pada kelompok kontrol sebanyak 4 responden. Pada kelompok responden dengan perlakuan yang umur kehamilan trimester II sebanyak 3 responden sedangkan pada kelompok kontrol sebanyak 2 responden. Pada kelompok responden dengan perlakuan yang umur kehamilan trimester III sebanyak 1 responden sedangkan pada kelompok kontrol sebanyak 1 responden.

Berdasarkan umur kehamilan Trimester pertama pada umur kehamilan 012 minggu dianggap sebagai periode penyesuaian. Penyesuaian yang dilakukan oleh wanita adalah kenyataan bahwa diasedang mengandung. Penerimaan kenyataan ini sangat penting bagi dirinya dan peran psikologi yang paling penting pada trimester pertama kehamilan. Hubungan antara stress dengan hipertensi diperkirakan melalui aktifitas saraf simpatik, yang dapat meningkatkan tekanan darah secara intermiten. Apabila stress menjadi 
berkepanjangan, akibat tekanan darah akan menetap tinggi. Stres atau ketegangan jiwa (rasa tertekan, murung, bingung, cemas, berdebar-debar, rasa marah, dendam, rasa takut, rasa bersalah) dapat merangsang kelenjar anak ginjal melepaskan hormon adrenalin dan memacu jantung berdenyut lebih cepat serta lebih kuat, sehingga tekanan darah akan meningkat. Jika stres berlangsung cukup lama, tubuh berusaha mengadakan penyesuaian sehingga timbul kelainan organis atau perubahan patologis. ${ }^{2,10}$

Berdasarkan tabel 1 karakteristik berdasarkan Riwayat Paritas. Pada kelompok responden dengan perlakuan yang mengalami hipertensi pada primigravida sebanyak 1 responden sedangkan pada kelompok kontrol sebanyak 2 responden. Pada kelompok responden dengan perlakuan yang mengalami hipertensi pada multigravida sebanyak 7 responden sedangkan pada kelompok kontrol sebanyak 5 responden,

Hubungan antara paritas pada ibu hamil terhadap tingkat terjadinya hipertensi dari penelitian ini terlihat bahwa pada responden multigravida lebih banyak terjadi hipertensi baik yang dengan perlakuan dan kelompok kontrol. Preeklampsia adalah penyakit dengan gejala klinis berupa hipertensi dan proteinuria yang timbul karena kehamilan akibat vasospasme dan aktivasi endotel saat usia kehamilan di atas 20 minggu. Preeklampsia merupakan salah satu penyulit dalam kehamilan yang menyebabkan sakit berat, kecacatan jangka panjang, serta kematian pada ibu, janin dan neonatus. Dari penelitian yang sebelumnya pernah dilakukan bahwasanya hipertensi lebih banyak terjadi pada primigravida, namun dalam penelitian ini lebih banyak pada multigravida, penyebabnya hipertensi lebih banyak pada multigravida karena pengaruhnya bisa disebabkan karena genetik, dan bisa juga disebabkan oleh obesitas, atau pengaruhnya bisa disebabkan oleh pola makan yang banyak mengandung garam, atau bisa juga karena makan yang fast food. ${ }^{2}$

Ada pengaruh dalam pemberian pijat kaki dengan minyak lavender pada ibu hamil dengan hipertensi. berdasarkan hasil analisa data dapat disimpulkan bahwa rata-rata penurunan tekanan darah sebelum diberikan perlakuan sampai selesai perlakuan terjadi pada pengukuran hari ke tujuh. Di mana adanya peningkatan tekanan darah disebabkan oleh melambatnya aliran darah dari bawah menuju ke atas karena tekanan pembesaran janin didalam perut sehingga vaskularisasi tidak lancer yang biasanya juga ditandai dengan adanya pembengkakan pada tungkai, selain itu terjadinya peningkatan tensi darah disebabkan oleh peningkatan hormon stress pada ibu hamil yang mempengaruhi psikologi dari ibu hamil. Sehingga dengan diberikan pijat kaki maka akan bisa melancarkan dari vaskularisasi darah. 
Hasil penelitian menunjukkan bahwa masase kaki merupakan terapi yang sangat efektif. Masase kaki baik untuk merilekskan otot-otot, mengurangi nyeri, memperbaiki organ tubuh, memperbaiki postur tubuh, dan sebagai latihan pasif. ${ }^{11}$ Selain itu Masase merupakan teknik integrasi sensori yang mempengaruhi aktivitas sistem saraf otonom. Apabila seseorang mempersepsikan sentuhan sebagai stimulus rileks maka akan muncul respon relaksasi. Tekanan darah diatur oleh serangkaian saraf otonom dan hormon yang memonitor volume darah dalam sirkulasi, diameter pembuluh darah, dan kontraksi jantung. Setiap faktor ini secara intrinsik berkaitan erat dengan pengaturan tekanan darah di dalam pembuluh darah. Nilai pembuluh darah bergantung pada kekuatan kontraksi jantung, diameter pembuluh darah, dan volume darah di dalam sirkulasi. sebagai stimulus rileks maka akan muncul respon relaksasi.

Penurunan tekanan darah disebabkan oleh terjadi relaksasi otot para responden. Responden diberikan intervensi masase kaki 7 kali selama 1 minggu berturut-turut yang mana otot-otot menjadi rileks. Rileksnya otototot akan menyebabkan terjadinya penurunan tekanan darah bagi para responden.

Gerakan masase kaki terdiri dari gerakan effleurage, masase pada kaki, effleurage. Gerakan ini bersifat berkesinambungan atau alirannya tidak terputus-putus agar energi mengalir dari satu meridian ke meridian lainnya dalam urutan yang teratur. ${ }^{12}$ Oleh karena itu, pemijatan yang dilakukan tangan sama sekali tidak boleh diangkat karena akan memutuskan aliran pijat sebagai satu kesatuan yang utuh, tangan harus selalu menyentuh tubuh dalam semua gerakan maju mundur yang dilakukan secara berurutan. ${ }^{5}$ Prinsipnya, pijat yang dilakukan pada penderita hipertensi adalah untuk memperlancar aliran energi didalam tubuh sehinga gangguan penyakit hipertensi dan komplikasinya dapat diminimalisir. Ketika semua jalur energi terbuka dan aliran energi tidak lagi terhalang oleh ketegangan otot dan hambatan lain maka resiko hipertensi dapat ditekan. ${ }^{3}$

Sedangkan aromaterapi merupakan cara efektif dan lembut untuk meningkatkan kesehatan tubuh, mengatasi gangguan gangguan ringan, serta membuat rileks. ${ }^{13}$ Sebagaimana dengan pijat, aromaterapi bisa membantu penyembuhan penderita hipertensi dalam membebaskan mereka dari stres, maupun gejala-gejala lain yang terkait dengan stres seperti kecemasan, insomnia,hingga depresi. Menghirup minyak aromaterapi sendiri dianggap sebagai cara penyembuhan yang paling langsung dan cepat. Hal ini dikarenakan molekul-molekul minyak essensial yang mudah menguap bereaksi langsung pada organ penciuman dan langsung dipersepsikan oleh otak. Minyak esensial seperti lavender, ylangylang, helichrysum, marjoram, dan lemon biasanya digunakan untuk menurunkan 
tekanan darah tinggi. Lavender diketahui efektif terhadap kecemasan, stres dan depresi sebagai sebuah obat penenang yang kuat, memulihkan kelelahan otot dan membantu sirkulasi darah Lavender mengandung sebagian besar ester (26\%$52 \%$ ), yang mana dapat menenangkan dan memberikan efek langsung pada sistem saraf. $^{14}$

Dengan dilakukannya masase pada daerah kaki dengan menggunakan esensial oil lavender, diharapkan aliran darah balik menuju jantung menjadi lancar serta terciptanya respon relaksasi yang memberikan efek vasodilatasi pada pembuluh darah dan merangsang aktivitas saraf parasimpatis hingga pada akhirnya akan menurunkan tekanan darah. Dalam hal ini, massase ekstrimitas dengan esensial oil lavender dapat menghasilkan relaksasi oleh stimulasi taktil jaringan tubuh menyebabkan respon neuro humoral yang komplek dalam The Hypothalamic-Pituitary Axis (HPA) ke sirkuit melalui jalur sistem saraf.

Adaptasi stres diatur oleh kapasitas HPA untuk mensekresikan hormon seperti kortisol dan endorphin yang mengurangi aktivitas sistem saraf simpatik dan meningkatkan respon saraf parasimpatis. Kortisol adalah hormon stress yang utama dan produk akhir dalam saraf simpatis. Sedangkan esensial minyak lavender bekerja merangsang sel saraf penciuman dan mempengaruhi kerja sistem limbik dengan meningkatkan perasaan positif dan rileks.
Sewaktu menarik nafas rangsangan bau mendatangi sel-sel pengindra lewat difusi melalui udara. Molekul bau terikat langsung melalui reseptor pembau atau ke protein pengikat spesifik yang membawa bau ke reseptor dan menyebabkan saraf menyalakan potensial aksi. Seluruh peristiwa disampaikan ke sistem limbik yang bertanggung jawab terhadap emosi dan otak mendaftar sebagai bau yang spesifik otak kemudian mengeluarkan serotonin yang membuat perubahan fisiologis pada tubuh, pikiran dan jiwa dan menghasilkan efek menenangkan pada tubuh. Dengan demikian, kerja jantung tidak membutuhkan tekanan kuat untuk memompa dan peredaran darah ke seluruh tubuh akan maksimal. ${ }^{15}$

\section{KESIMPULAN}

Terdapat pengaruh Pijat Kaki pada Ibu Hamil terhadap penurunan tekanan darah pada ibu hamil dengan hipertensi di RS Pratama Yogyakarta dan RS PKU Muhamadiyah Yogyakarta.

Saran diberikan kepada Ibu Hamil diharapkan ibu hamil yang mengalami hipertensi melakukan ANC secara teratur, meminum obat farmasi dan melakukan terapi nor farmakologi dengan pijat kaki.

\section{TERIMA KASIH}

1. Ibu Sarwinanti, M.Kep.,Sp.Mat beserta Tim LPPM, LPPM Universitas 'Aisyiyah Yogyakarta, email www.unisayogya.ac.id

2. Direktur PKU Muhammadiyah Yohyakarta 
info@.pkugamping.com

3. Direktur RS Pratama Kota Yogyakarta rspratama@jogyakota.go.id

\section{KEPUSTAKAAN}

1. Aulia Sani; Harmani Kalim. Diagnosis dan Tatalaksana Hipertensi, Sindrom Koroner Akut,dan Gagal Jantung. Jakarta:Medya crea. 2008.

2. Prawirohardjo, S. IImu Kebidanan. Penerbit Yayasan Bina Pustaka Sarwono Prawirohardjo: Jakarta. 2014.

3. Dalimartha, Setiawan. Care Your Self Hipertensi. Penebar Plus: Jakarta. 2008.

4. Howatson G, Gaze D, Someren K.A.2005. The Efficacy Of Ice Massage In The Treatment Of Exercise Induced Muscle Damage. Scandinavian journal of medicine \& science in sports.2005;15;416-422.

5. Price, P. Aromaterapi bagi Profesi Kesehatan. Penerbit Buku Kedokteran EGC: Jakarta, 1997

6. Koensoemardiyah., Aromaterapi Untuk Kesehatan, Kebugaran dan Kecantikan. Lily Publisher: Yogyakarta. 2009.

7. Shinobi. Pijat Aromaterapi. 2008. Diakses dari http: //id.88db.com /id/Discussion/Discussion_reply.page/H ealth_Medical/?Di pada $2 \overline{9}$ Mei 2017.

8. Nursalam. Metodelogi Penelitian ilmu Keperawatan. Gramedia, 2012.

9. Kowalski, R. E. Terapi hipertensi: program 8 minggu menurunkan tekanan darah tinggi dan mengurangi risiko serangan jantung dan stroke secara alami. Bandung: Penerbit Qanita. 2010.

10. Sukfrianty. S,. Faktor Risiko Hipertensi pada Ibu Hamil di RS Hikmah Kota Makasar. 2016.

11. Potter dan Perry. Fundamental Keperawatan Buku 3. Edisi 7. Salemba Medika: Jakarta. 2010.

12. Hemmings, B. J. Physiological, psychological and performance effects of massage therapy: a review of the literature 1. Physical Therapy in Sport 2(4): 165. 2001.
13. Lee, G, Bae, H. Therapeutic effects of phytochemicals and medicinal herbs on depression. BioMed Research International. 2017.

14. Andria, Agusta. Aroma Terapi Cara Sehat dengan Wewangian Alami. Jakarta: Penerba Swadaya. 2014.

15. Zaidah L, Perbedaan Pengaruh Foam roller massage dan ice massage terhadap keletihan otot, Universitas Sebelas Maret. 2016. Tesis Respository. 